\title{
Pitting Corrosion Resistance of Ultrafine-Grained Aluminum Processed by Severe Plastic Deformation*1
}

\author{
In-Joon Son ${ }^{1, * 2}$, Hiroaki Nakano ${ }^{2}$, Satoshi Oue ${ }^{2}$, Shigeo Kobayashi ${ }^{3}$, \\ Hisaaki Fukushima ${ }^{2}$ and Zenji Horita ${ }^{2}$ \\ ${ }^{1}$ Department of Materials Process Engineering, Kyushu University, Fukuoka 812-8581, Japan \\ ${ }^{2}$ Department of Materials Science \& Engineering, Kyushu University, Fukuoka 812-8581, Japan \\ ${ }^{3}$ Department of Applied chemistry and Biochemistry, Kyushu Sangyo University, Fukuoka 813-8503, Japan
}

The effect of equal-channel angular pressing (ECAP) on the pitting corrosion resistance of Al and Al-Mg alloy was investigated by means of polarization curves in solutions containing $300 \mathrm{ppm}$ of $\mathrm{Cl}^{-}$and by surface analysis. The potentials for pitting corrosion of $\mathrm{Al}$ and $\mathrm{Al}-\mathrm{Mg}$ alloy were clearly shifted in the noble direction by the ECAP process, indicating that this process improves resistance to pitting corrosion. SEM observations revealed that pitting corrosion occurred near impurity precipitates and that the size of the impurity precipitated decreased as a result of the ECAP process. The time-dependence of corrosion potential and the polarization resistance determined using the AC impedance technique suggest that the ECAP process increases the rate of formation of $\mathrm{Al}$ oxide films. The improvement in pitting corrosion resistance of $\mathrm{Al}$ and $\mathrm{Al}-$ $\mathrm{Mg}$ alloy by ECAP appears to be attributable to a decrease in the size of impurity precipitates and an increase in the rate of formation of $\mathrm{Al}$ oxide films.

(Received December 2, 2005; Accepted February 8, 2006; Published April 15, 2006)

Keywords: aluminum, aluminum-magnesium alloy, equal-channel angular pressing, corrosion resistance, pitting corrosion

\section{Introduction}

Although aluminum is inherently an active metal, it shows excellent corrosion resistance over a neutral range of $\mathrm{pH} 4-8$ due to its superficial oxide film. However, in solutions containing $\mathrm{Cl}^{-}$, pitting corrosion occurs locally where the oxide film is attacked by $\mathrm{Cl}^{-}$. ${ }^{1,2)}$ Selection of alloying elements, cathodic protection and the organic coating are therefore performed to improve the pitting corrosion resistance of $\mathrm{Al}$ alloys. However, these techniques result in poor mechanical properties and increase processing costs. On the other hand, reducing the grain size of metallic materials to the submicrometer range or even the nanometer range using the equal-channel angular pressing (ECAP) process is increasingly being studied with the aim of improving mechanical properties such as strength and ductility. ${ }^{3-8)}$ However, there have been very few studies on the effect of grain size reduction by means of the ECAP process on the resistance to pitting corrosion of $\mathrm{Al}$ alloys. ${ }^{9,10)}$ It is also necessary to elucidate the mechanism by which the pitting corrosion resistance of $\mathrm{Al}$ alloys is changed by the ECAP process. The conventional rolling process seems to have only a minor effect, since reduction of the impurity precipitate size and the Al grain size are very slight as compared with the ECAP process. Therefore, the effect of the conventional rolling process on pitting corrosion resistance has so far been little reported. In this study, the pitting corrosion resistance of $\mathrm{Al}$ and $\mathrm{Al}-\mathrm{Mg}$ alloy produced by the ECAP process was investigated using electrochemical techniques. In addition, the mechanism of improvement of the pitting corrosion resistance of $\mathrm{Al}$ and $\mathrm{Al}-\mathrm{Mg}$ alloy with ECAP was clarified by surface analysis and electrochemical impedance methods.

\footnotetext{
*1 This Paper was Originally Published in Japanese in J. Jpn. Inst. Metals 69 (2005) 892-898.

${ }^{*}$ Graduate Student, Kyushu University
}

\section{Experimental}

AA1 100 (mass $\%,>99.0 \%$ Al, $0.15 \% \mathrm{Cu}, 0.09 \% \mathrm{Si}, 0.60 \%$ $\mathrm{Fe}, 0.005 \% \mathrm{Mn}, 0.006 \% \mathrm{Zn}, 0.002 \% \mathrm{Mg},<0.001 \% \mathrm{Cr}$ ) and AA5052 $(0.05 \% \mathrm{Cu}, 0.11 \% \mathrm{Si}, 0.24 \% \mathrm{Fe}, 0.01 \% \mathrm{Mn}, 2.5 \%$ $\mathrm{Mg}, 0.01 \% \mathrm{Zn}, 0.17 \% \mathrm{Cr},<0.15 \%$ other elements, rest $\mathrm{Al}$ ) were respectively used as specimens of $\mathrm{Al}$ and $\mathrm{Al}-\mathrm{Mg}$ alloy. Figure 1 shows a schematic diagram of the ECAP process. ECAP was conducted for 8 passes (Al) or 4 passes $(\mathrm{Al}-\mathrm{Mg})$ at room temperature using a die with a channel angle of $90^{\circ}$, which creates an equivalent strain of $\sim 1$ during one passage through the die. The sample was rotated by $90^{\circ}$ about the longitudinal axis in the same sense between consecutive passes, the generally designated processing route $\mathrm{Bc} .{ }^{6)}$ The

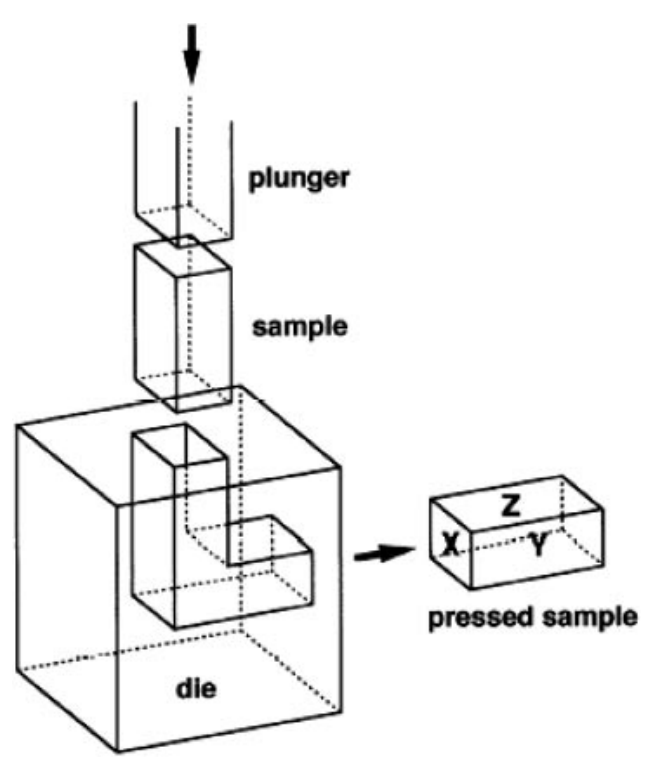

Fig. 1 Schematic diagram of ECAP. 

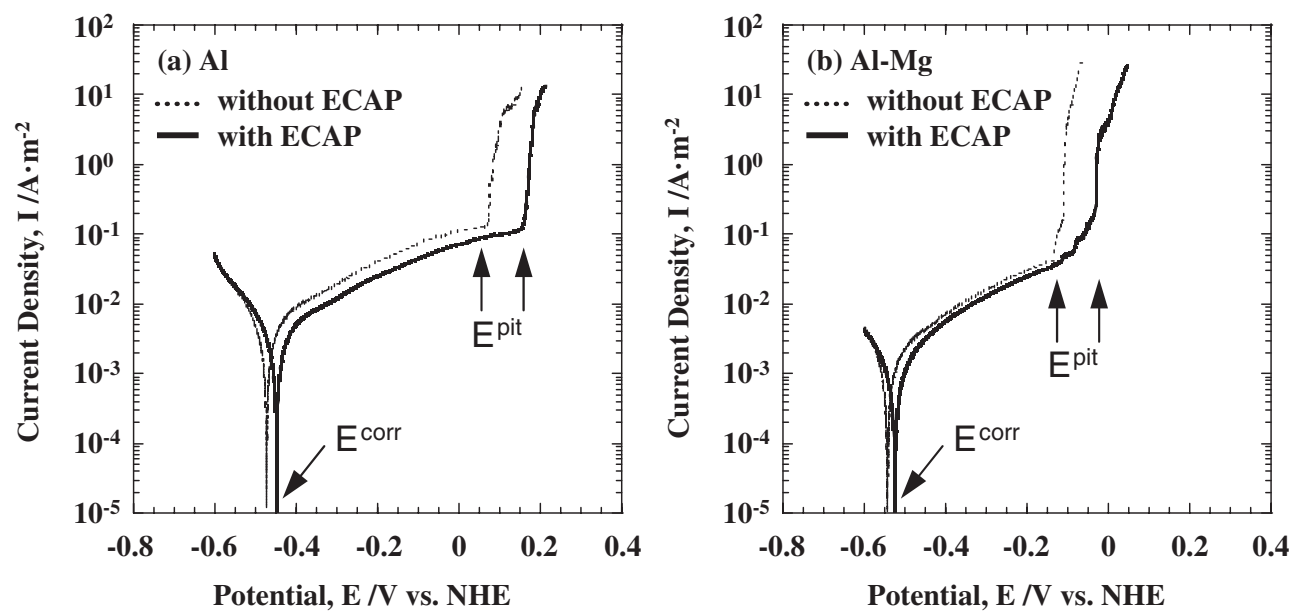

Fig. 2 Effect of ECAP on the polarization curves of $\mathrm{Al}$ (a) and $\mathrm{Al}-\mathrm{Mg}$ alloy (b) in a solution containing $0.1 \mathrm{~mol} \cdot \mathrm{L}^{-1}$ of $\mathrm{Na}_{2} \mathrm{SO}_{4}$ and $300 \mathrm{ppm} \mathrm{Cl}^{-}$.
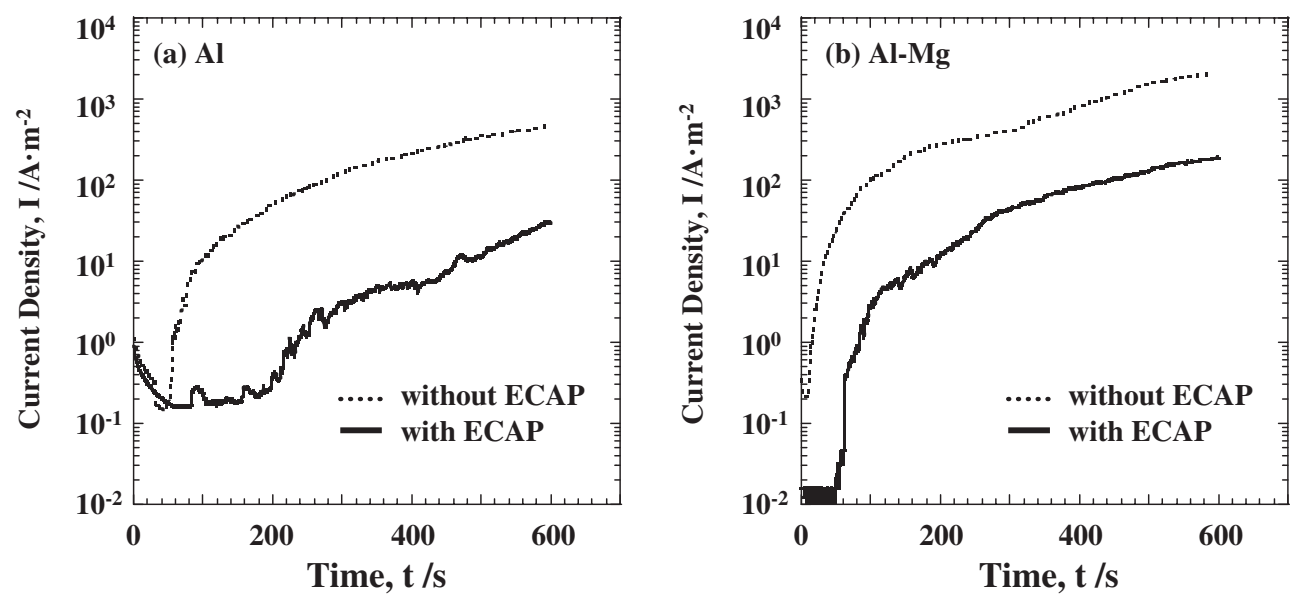

Fig. 3 Time-dependence of the anodic current density of $\mathrm{Al}$ (a) and $\mathrm{Al}-\mathrm{Mg}$ alloy (b) while kept at constant potentials of $0.2 \mathrm{~V}$ and $0 \mathrm{~V}$ nobler than their pitting corrosion potential.

pressings were performed at a rate of $\sim 19 \mathrm{~mm} \mathrm{~s}^{-1}$ using $\mathrm{MoS}_{2}$ as a lubricant. The initial grain sizes of $\mathrm{Al}$ and $\mathrm{Al}-\mathrm{Mg}$ alloy prior to ECAP were $30-50 \mu \mathrm{m}$. The average grain sizes of $\mathrm{Al}$ and $\mathrm{Al}-\mathrm{Mg}$ alloy after the ECAP process were confirmed by TEM observation to be respectively $0.5-$ $1.0 \mu \mathrm{m}$ and $0.2-0.5 \mu \mathrm{m} .{ }^{11)}$

After $\mathrm{Al}$ and $\mathrm{Al}-\mathrm{Mg}$ alloy were carefully polished down with No. 600 emery paper and immersed in a solution containing $0.1 \mathrm{~mol} / \mathrm{L}$ of $\mathrm{Na}_{2} \mathrm{SO}_{4}$ and $8.46 \mathrm{~m} \mathrm{~mol} / \mathrm{L}$ of $\mathrm{NaCl}$ $\left(300 \mathrm{ppm} \mathrm{Cl}^{-}\right)$at $25^{\circ} \mathrm{C}$ for an hour in an air atmosphere, the polarization curves were measured by polarizing from the less noble potential to the anodic potential direction using the potential sweep method at $30 \mathrm{mV} \mathrm{min}^{-1}$. The electrode potentials were measured during the potential sweep using a saturated $\mathrm{Ag} / \mathrm{AgCl}$ reference electrode $(0.199 \mathrm{~V}$ vs. NHE, $25^{\circ} \mathrm{C}$ ). In the presentation of polarization curves, the potentials were plotted with reference to NHE.

Since the naturally formed Al oxide films are of the barrier type, the time-dependences of anode potential were examined during galvanostatic electrolysis at $1 \mathrm{~A} / \mathrm{m}^{2}$ in a solution containing $0.5 \mathrm{~mol} / \mathrm{L}$ of $\mathrm{H}_{3} \mathrm{BO}_{3}$ and $0.05 \mathrm{~mol} / \mathrm{L}$ of $\mathrm{Na}_{2} \mathrm{~B}_{4} \mathrm{O}_{7} \cdot 10 \mathrm{H}_{2} \mathrm{O}$ to form a barrier-type oxide film. The effect of ECAP on the rate of formation of Al oxide film was assumed to be revealed by these time-dependences of anode potentials.

The AC impedance of the $\mathrm{Al}$ and $\mathrm{Al}-\mathrm{Mg}$ alloy was measured at rest potential in a solution containing $0.1 \mathrm{~mol} / \mathrm{L}$ of $\mathrm{Na}_{2} \mathrm{SO}_{4}$ and $8.46 \mathrm{~m} \mathrm{~mol} / \mathrm{L}$ of $\mathrm{NaCl}$. To obtain Cole-Cole plots, the frequency dependence of the $\mathrm{AC}$ impedance and phase difference were measured using a frequency response analyzer at rest potential $\left( \pm 100 \mathrm{mV}\right.$ sine wave, $10^{-1}-10^{4} \mathrm{~Hz}$, 10 points/decade).

The morphology of $\mathrm{Al}$ and $\mathrm{Al}-\mathrm{Mg}$ alloy with and without ECAP and the morphology of pitting corrosion were observed by SEM and EPMA.

\section{Results and Discussion}

\subsection{Effect of ECAP on the pitting corrosion resistance of $\mathrm{Al}$ and $\mathrm{Al}-\mathrm{Mg}$ alloy}

Figure 2 shows the effect of ECAP on the polarization curve of $\mathrm{Al}$ and $\mathrm{Al}-\mathrm{Mg}$ alloy. The anodic current densities rapidly increased at certain potentials when the anode potentials were shifted from their corrosion potential to the 
noble direction. This rapid increase in current density is caused by initiation of pitting corrosion. The pitting corrosion potentials, at which pitting corrosion is initiated, were evidently shifted to the noble direction by ECAP, indicating improvement in the pitting corrosion resistance by application of ECAP. On the other hand, the corrosion potentials of $\mathrm{Al}$ and $\mathrm{Al}-\mathrm{Mg}$ alloy were also slightly shifted to the noble direction by ECAP. The corrosion potential of $\mathrm{Al}$ was nobler than that of Al-Mg alloy and the current density needed to initiate pitting corrosion was smaller in $\mathrm{Al}-\mathrm{Mg}$ alloy than in Al. These results indicate that the pitting corrosion resistance of $\mathrm{Al}$ is better than $\mathrm{Al}-\mathrm{Mg}$ alloy.

Figure 3 shows the time-dependence of the anodic current density of $\mathrm{Al}$ and $\mathrm{Al}-\mathrm{Mg}$ alloy while kept at constant potentials of respectively $0.2 \mathrm{~V}$ and $0 \mathrm{~V}$ to be nobler than their pitting corrosion potentials. The anodic current densities of $\mathrm{Al}$ and $\mathrm{Al}-\mathrm{Mg}$ alloy increased sharply after certain periods of time due to the initiation of pitting corrosion. The time required before initiating pitting corrosion of $\mathrm{Al}$ and $\mathrm{Al}-\mathrm{Mg}$ alloy was longer with ECAP than without. Further, the anodic current densities of pitting corrosion were smaller with ECAP than without.

\subsection{Observation of pitting corrosion area}

Figure 4 shows EPMA images of Al produced with ECAP. The back electron image (a) reveals the existence of secondphase precipitates, shown by the arrow in Fig. 4. It was found from the characteristic X-ray images of $\mathrm{Al}(\mathrm{b}), \mathrm{Fe}(\mathrm{c})$ and $\mathrm{Si}(\mathrm{d})$ that these precipitates included $\mathrm{Fe}$ but no $\mathrm{Si}$. Al without ECAP also showed the same trend as Al with ECAP. It is well known that $\mathrm{Fe}-\mathrm{Al}$ intermetallic compounds precipitate in $\mathrm{Al}$
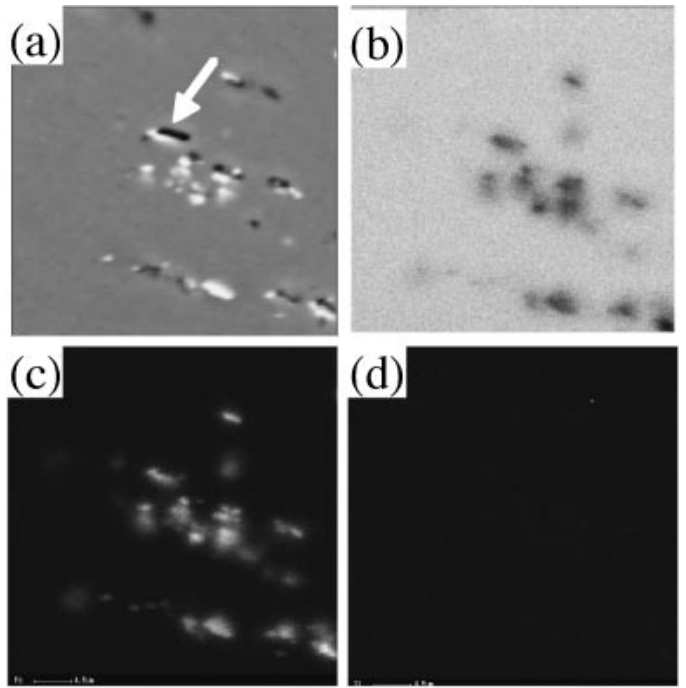
(a) BEI
(b) $\mathrm{Al}$
(c) $\mathrm{Fe}$
(d) $\mathrm{Si}$
$5 \mu \mathrm{m}$

Fig. 4 EPMA images of Al with ECAP

containing trace amounts of Fe. ${ }^{12)}$ The precipitates observed in Fig. 4 therefore appear to be $\mathrm{Fe}-\mathrm{Al}$ intermetallic compounds such as $\mathrm{Al}_{3} \mathrm{Fe}$ and $\mathrm{Al}_{6} \mathrm{Fe}$. On the other hand, the precipitates in $\mathrm{Al}-\mathrm{Mg}$ alloy included $\mathrm{Si}$ or $\mathrm{Fe}$, indicating the presence of trace $\mathrm{Si}$ and $\mathrm{Fe}-\mathrm{Al}$ intermetallic compounds.

The surfaces of $\mathrm{Al}$ and $\mathrm{Al}-\mathrm{Mg}$ alloys after immersion in the solution containing $0.6 \mathrm{~mol} / \mathrm{L}$ of $\mathrm{NaCl}$ for 36 hours were analyzed by SEM and EDX. Figure 5 shows the SEM images and EDX spectra. Pits several micrometers in size were
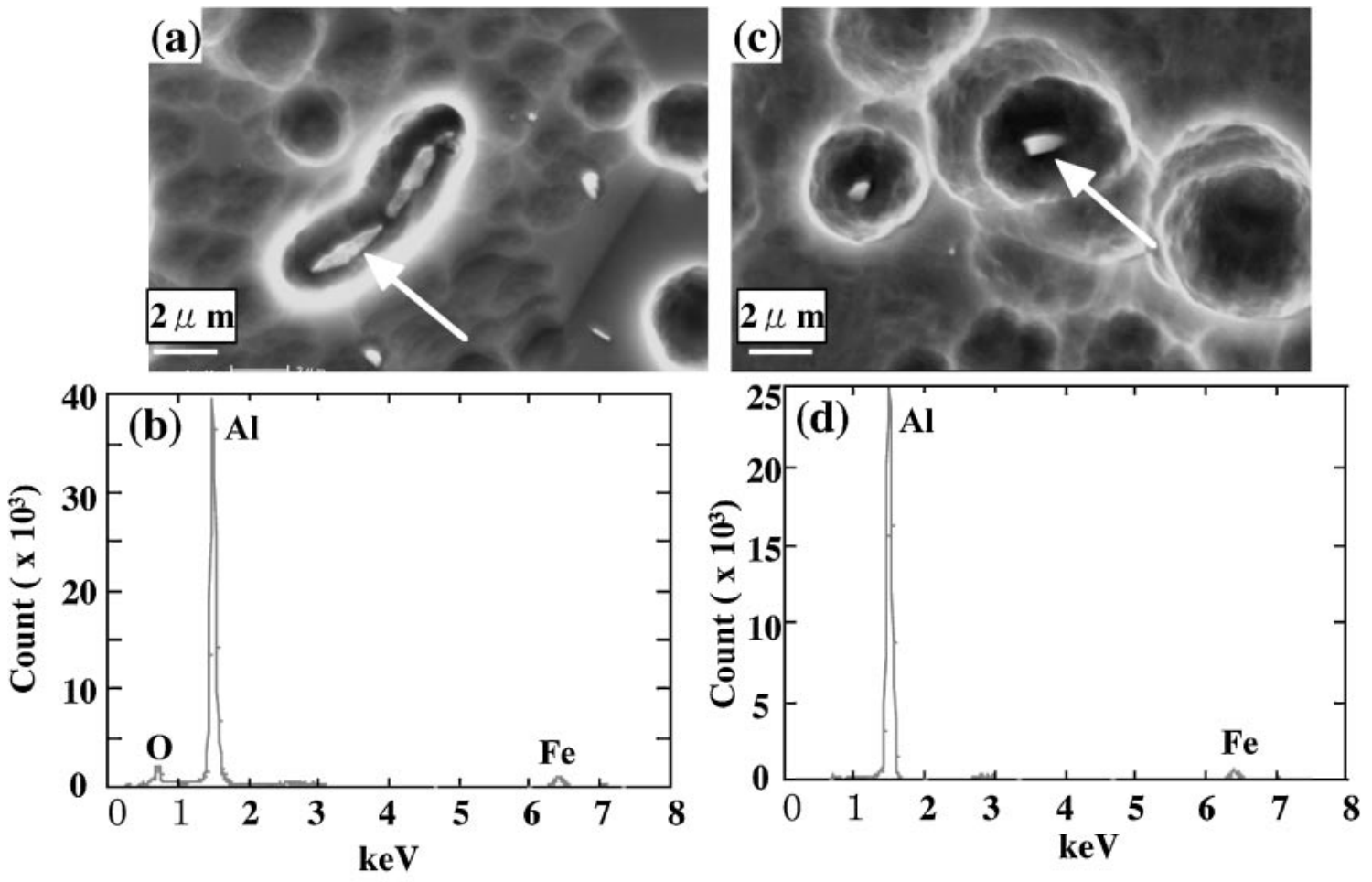

\section{(a), (b) : Al without ECAP \\ (c), (d) : Al with ECAP}

Fig. 5 SEM images and EDX spectra of $\mathrm{Al}$ after dipping in $0.6 \mathrm{~mol} \cdot \mathrm{L}^{-1}$ of $\mathrm{NaCl}$ solution for $36 \mathrm{~h}$. 

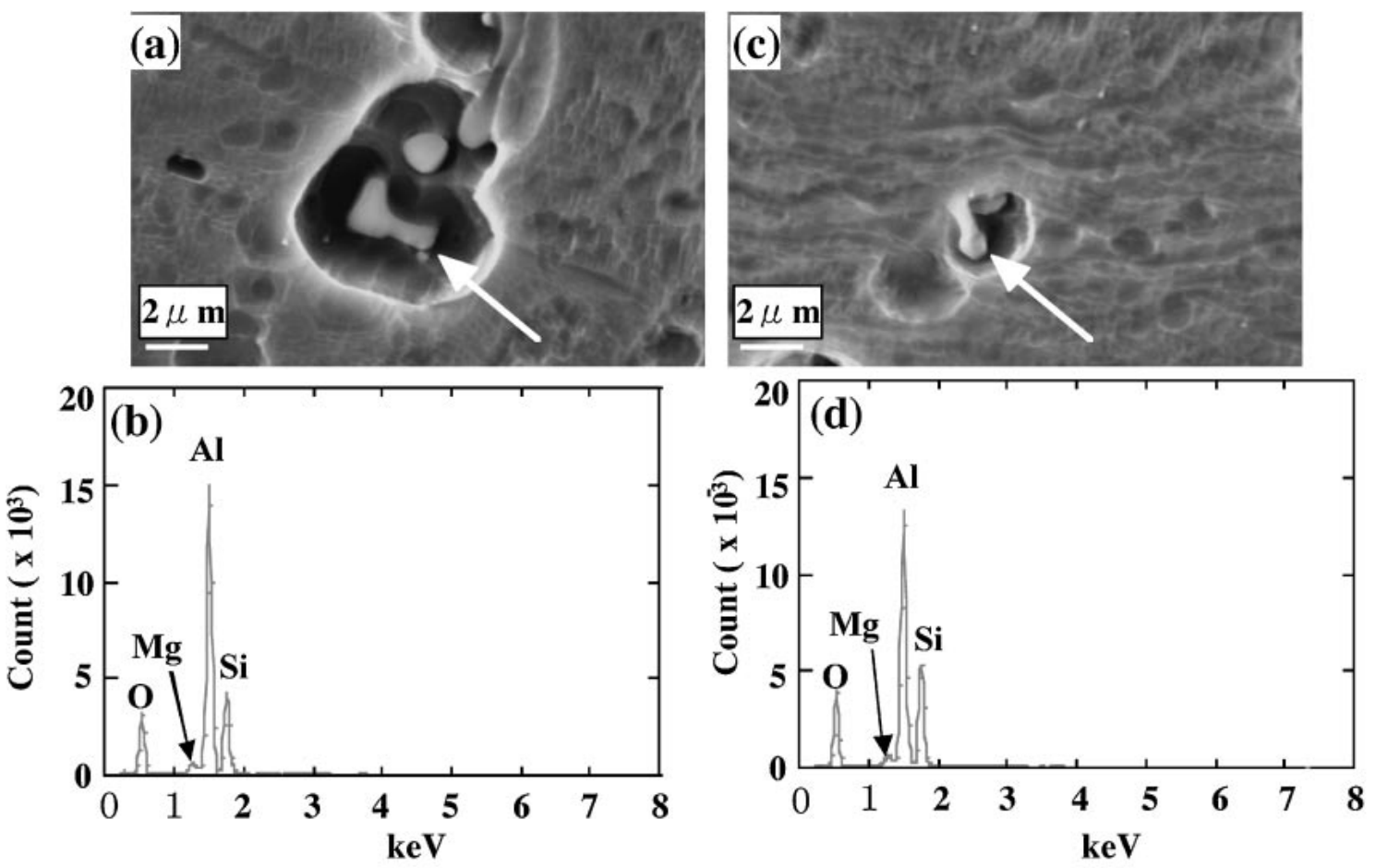

(a), (b) : Al-Mg without ECAP (c), (d) : Al-Mg with ECAP

Fig. 6 SEM images and EDX spectra of Al-Mg alloy after dipping in $0.6 \mathrm{~mol} \cdot \mathrm{L}^{-1}$ of $\mathrm{NaCl}$ solution for $36 \mathrm{~h}$.
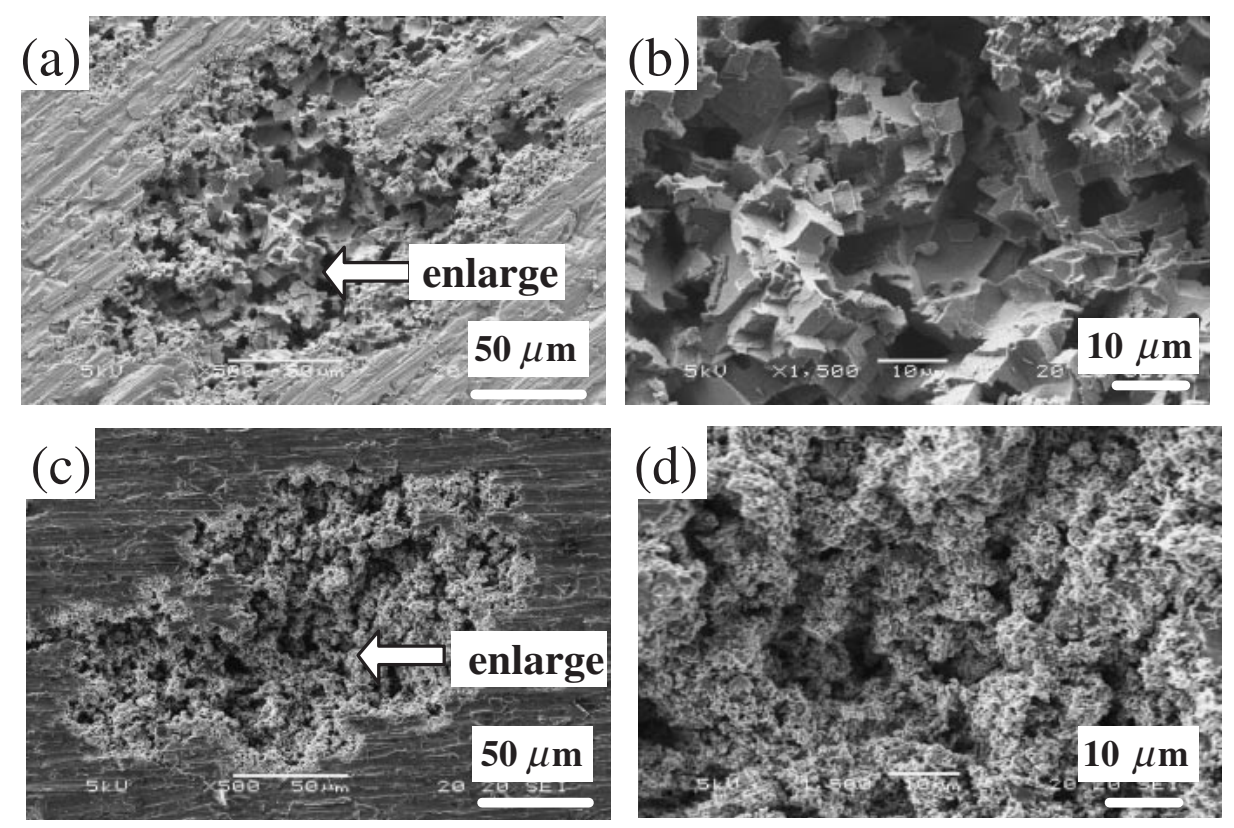
(a), (b) :without ECAP
(c), (d) : with ECAP

Fig. 7 Morphology of $\mathrm{Al}$ after anodic oxidation for $5 \mathrm{~min}$ at $0.2 \mathrm{~V}$ nobler than the pitting corrosion potential.

observed around the precipitates, shown with arrows in Fig. 5(a) and (c), irrespective of having undergone the ECAP process or not, indicating the initiation of pitting corrosion. EDX spectra (b) and (d) at areas marked with arrows in Fig. 5(a) and (c) show the presence of Fe, suggesting that theses precipitates are $\mathrm{Fe}-\mathrm{Al}$ intermetallic compounds. Since $\mathrm{Fe}-\mathrm{Al}$ intermetallic compounds are nobler than the $\mathrm{Al}$ matrix, ${ }^{2)}$ pitting corrosion of $\mathrm{Al}$ appears to occur by forming a local-action cell in which an $\mathrm{Fe}-\mathrm{Al}$ intermetallic compound acts as the cathode. 

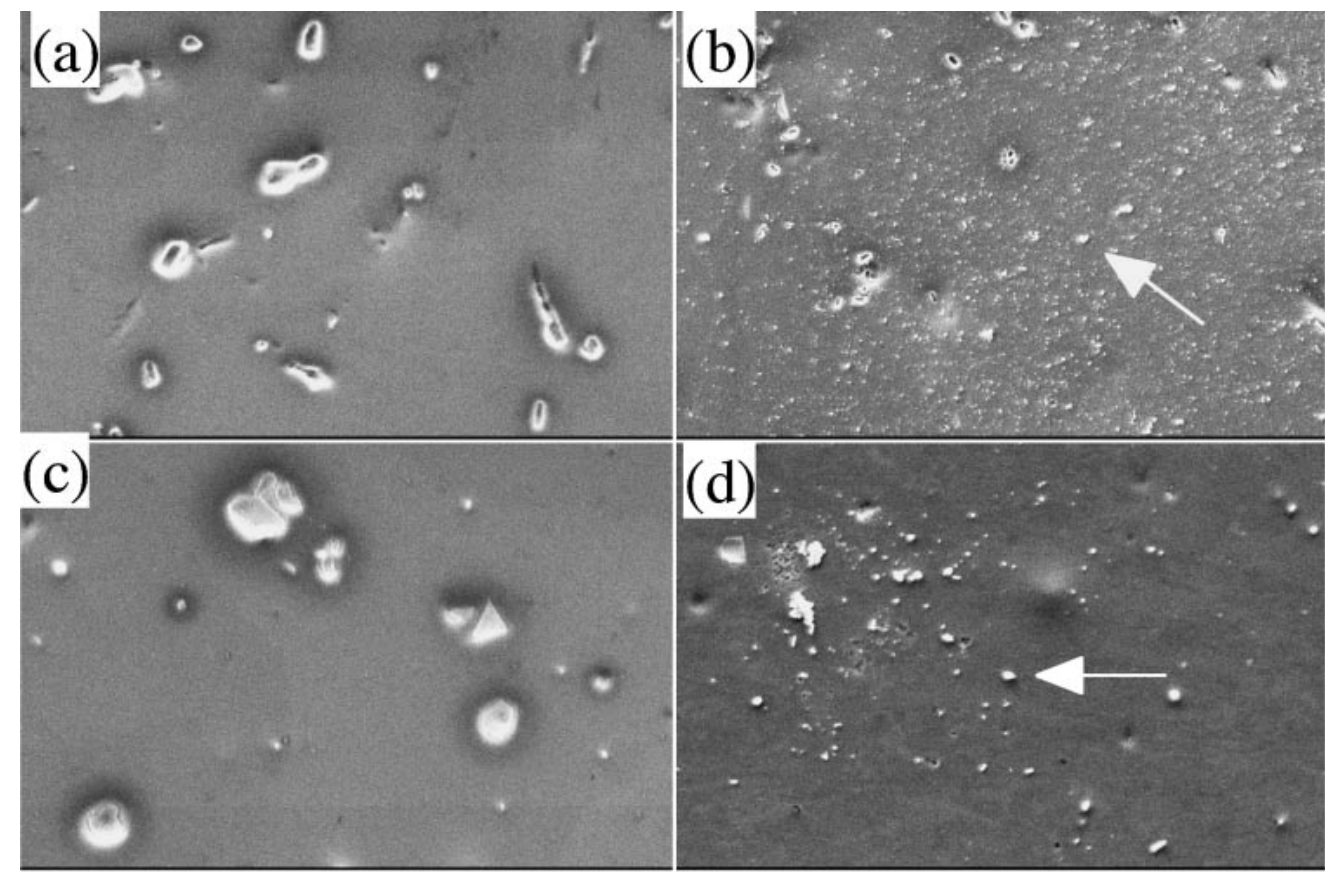

(a) Al without ECAP

(b) Al with ECAP

(c) Al-Mg without ECAP

(d) Al-Mg with ECAP

$10 \mu \mathrm{m}$

Fig. 8 Effect of ECAP on the morphology of Al and Al-Mg alloy.
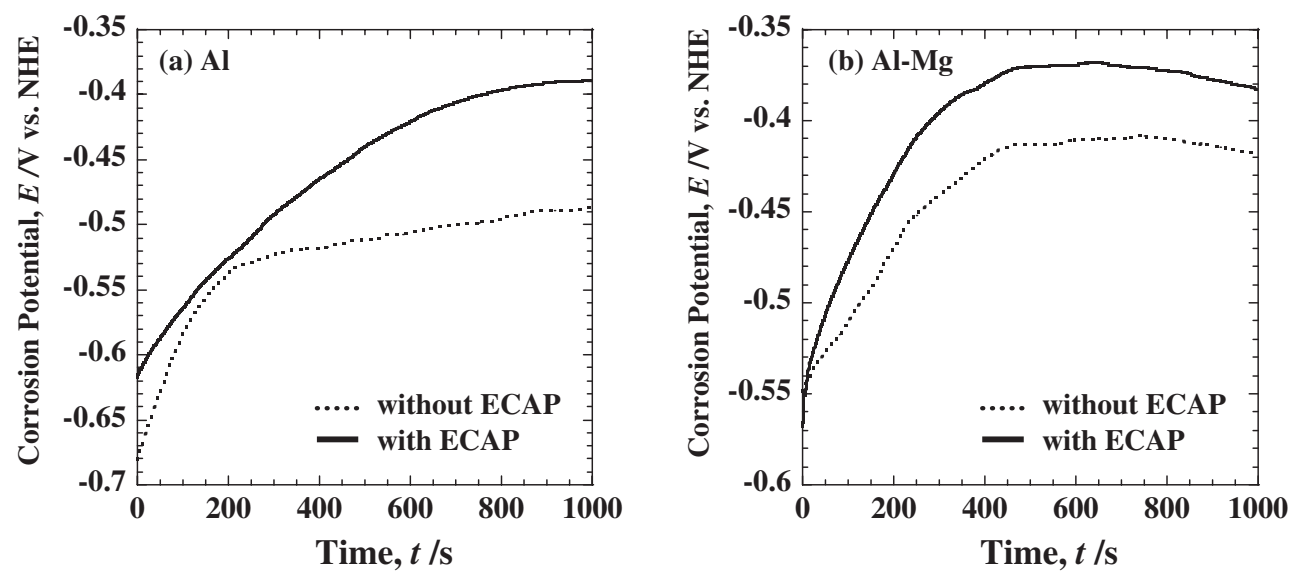

Fig. 9 Time-dependence of corrosion potential of $\mathrm{Al}(\mathrm{a})$ and $\mathrm{Al}-\mathrm{Mg}$ alloy (b) in a solution containing $0.1 \mathrm{~mol} \cdot \mathrm{L}^{-1}$ of $\mathrm{Na}_{2} \mathrm{SO}_{4}$ and $300 \mathrm{ppm}$ of $\mathrm{Cl}^{-}$at $25^{\circ} \mathrm{C}$.

Pits several micrometers in size were also observed around precipitates in $\mathrm{Al}-\mathrm{Mg}$ alloy irrespective of having undergone the ECAP process or not, as shown in Fig. 6. It was found from EDX spectra (b) and (d) at areas marked with arrows in Fig. 6(a) and (c) that the precipitate in Al-Mg alloy was trace $\mathrm{Si}$. In Al-Mg alloy, precipitation of $\mathrm{Fe}-\mathrm{Al}$ intermetallic compounds was also observed, but the pitting corrosion occurred mainly around $\mathrm{Si}$ precipitates. The immersion potentials of $\mathrm{Si}$ and $\mathrm{FeAl}_{3}$ in the solution containing $0.9 \mathrm{~mol} /$ $\mathrm{L}$ of $\mathrm{NaCl}$ at $298 \mathrm{~K}$ were respectively reported to be $-0.26 \mathrm{~V}$ and $-0.56 \mathrm{~V},{ }^{13)}$ showing that the difference in potential between the precipitate and $\mathrm{Al}$ matrix was greater in Si than in $\mathrm{FeAl}_{3}$. Local-action cells were therefore more easily to form around $\mathrm{Si}$ than around $\mathrm{FeAl}_{3}$, resulting in more intensive pitting corrosion around $\mathrm{Si}$.
Figure 7 shows the morphology of $\mathrm{Al}$ after anodic reaction for $5 \mathrm{~min}$ at $0.2 \mathrm{~V}$ nobler than the pitting corrosion potential in a solution containing $0.1 \mathrm{~mol} / \mathrm{L}$ of $\mathrm{Na}_{2} \mathrm{SO}_{4}$ and 8.46 $\mathrm{mmol} / \mathrm{L}$ of $\mathrm{NaCl}$. Crystallographic pits $100-200 \mu \mathrm{m}$ in size were observed in the both $\mathrm{Al}$ produced with and without ECAP, as shown in Fig. 7(a) and (c). As can be seen from the enlarged pitting areas in Fig. 7(b) and (d), since the grain size of Al greatly decreased with ECAP, the crystals in the pitting area were more compact with ECAP than without.

\subsection{Mechanism of improvement of pitting corrosion resistance with ECAP}

3.3.1 Decrease in size of the second-phase precipitates

Figure 8 shows the morphology of $\mathrm{Al}$ and $\mathrm{Al}-\mathrm{Mg}$ alloy with and without ECAP. The small precipitates in Fig. 8 were 

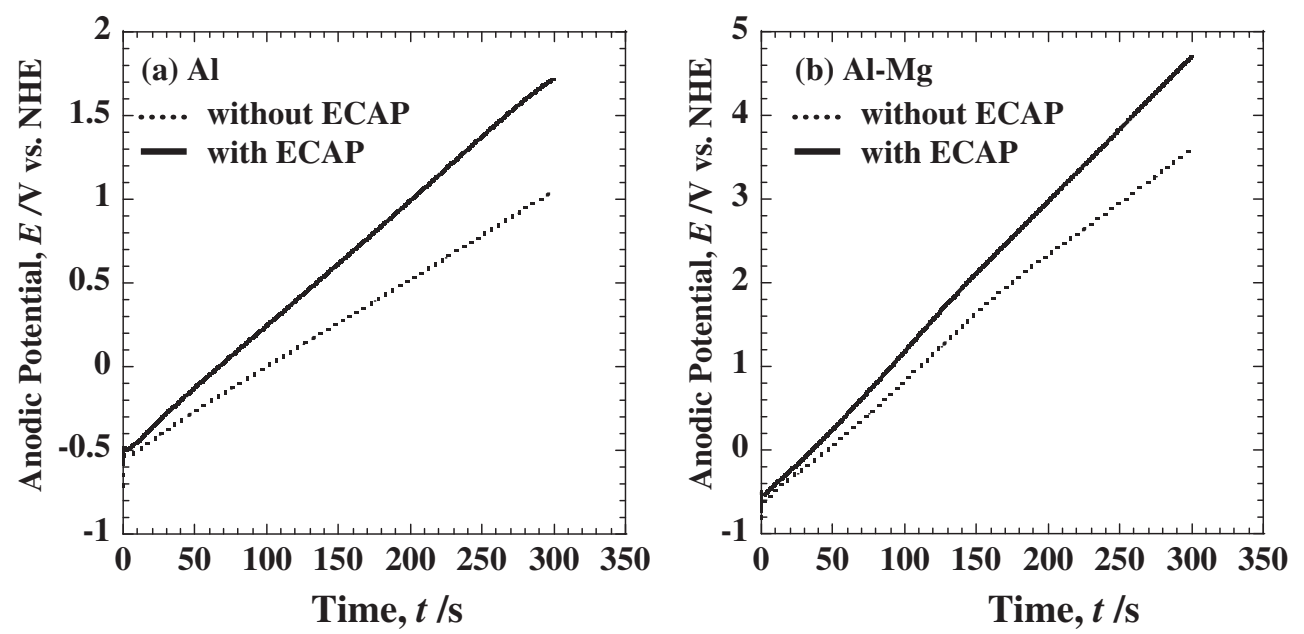

Fig. 10 Time-dependence of the anode potential of $\mathrm{Al}$ (a) and $\mathrm{Al}-\mathrm{Mg}$ alloy (b) at $1 \mathrm{~A} \cdot \mathrm{m}^{-2}$ in a solution containing $0.5 \mathrm{~mol} \cdot \mathrm{L}^{-1}$ of $\mathrm{H}_{3} \mathrm{BO}$ and $0.05 \mathrm{~mol} \cdot \mathrm{L}^{-1}$ of $\mathrm{Na}_{2} \mathrm{~B}_{4} \mathrm{O}_{7}$.

$\mathrm{Fe}-\mathrm{Al}$ intermetallic compounds and $\mathrm{Si}$. The precipitates were present, irrespective of having undergone the ECAP process or not; however, the size of the precipitates in $\mathrm{Al}$ and $\mathrm{Al}-\mathrm{Mg}$ alloy was greatly decreased by ECAP. It is well known that second-phase precipitates can be broken up by the ECAP process, ${ }^{7,8)}$ as was also found in this study. Since the precipitates of impurities act as cathodes for the Al matrix, the precipitates nucleate the pitting corrosion of Al. Pitting corrosion is less likely to occur with a decrease in the size of the precipitate, that is, with a decrease in cathode area. It has been reported from electron microscope observations that multiple pitting corrosion occurred at the initial stage, but only pits that grow readily at the initial stage ultimately develop into macro pits, since most pits are unstable and are immediately repassivated. ${ }^{2)}$ Pits readily grow around large precipitates at the initial stage and continue to grow to become macro pits. The improvement of pitting corrosion resistance with ECAP can thus be partially ascribed to a decrease in the size of the precipitates.

\subsubsection{Increment in rate of formation of Al oxide films}

Figure 9 shows the time-dependence of the corrosion potential of $\mathrm{Al}$ and $\mathrm{Al}-\mathrm{Mg}$ alloy in a solution containing $0.1 \mathrm{~mol} / \mathrm{L}$ of $\mathrm{Na}_{2} \mathrm{SO}_{4}$ and $300 \mathrm{ppm}$ of $\mathrm{Cl}^{-}$at $25^{\circ} \mathrm{C}$. All the corrosion potentials shifted in the noble direction with increased time. This can be ascribed to the $\mathrm{Al}$ oxide films that form naturally in the solution. The corrosion potentials of $\mathrm{Al}$ and $\mathrm{Al}-\mathrm{Mg}$ alloy shifted to the noble direction more rapidly with ECAP than without, suggesting that the rate of formation of $\mathrm{Al}$ oxide film increased with ECAP. It is well known that the oxidation reaction of metal occurs more quickly at crystalline lattice defects, such as grain boundaries and dislocations, because the lattice defects include segregated impurities. ${ }^{1,2)}$ The ECAP process markedly increases the number of grain boundaries and the dislocation density in $\mathrm{Al}$. The oxidation rate of $\mathrm{Al}$ appears to increase as a result of the increase in grain boundary and dislocation density caused by ECAP. It appears that a more rapid shift to the noble direction of the corrosion potential of $\mathrm{Al}$ and $\mathrm{Al}-\mathrm{Mg}$ alloy produced with ECAP is caused by an increase in the rate of formation of $\mathrm{Al}$ oxide films. In the discussion described above, the average magnitude of the oxidation rate of $\mathrm{Al}$ over the Al surface is taken into consideration, because it was estimated by the corrosion potential. Since pitting corrosion occurred around the precipitates, it is necessary to investigate the rate of formation of $\mathrm{Al}$ oxide films immediately around the precipitates. However, in this study, it was assumed that the oxidation rate of $\mathrm{Al}$ around the precipitates was almost identical to the average of that of the entire Al surface.

Since the naturally formed Al oxide films are of the barrier type, the anode potentials were measured during galvanostatic electrolysis in a neutral solution containing a boric salt to form a barrier-type oxide film. Figure 10 shows the timedependence of anode potentials of $\mathrm{Al}$ and $\mathrm{Al}-\mathrm{Mg}$ alloy at $1 \mathrm{~A} / \mathrm{m}^{2}$ in a solution containing $0.5 \mathrm{~mol} / \mathrm{L}$ of $\mathrm{H}_{3} \mathrm{BO}_{3}$ and $0.05 \mathrm{~mol} / \mathrm{L}$ of $\mathrm{Na}_{2} \mathrm{~B}_{4} \mathrm{O}_{7}$. The anode potentials of $\mathrm{Al}$ and $\mathrm{Al}-$ $\mathrm{Mg}$ alloy shifted to the noble direction with increased duration of electrolysis, and the shift was faster with ECAP than without. The shift of the anodic potential corresponds to the rate of formation of $\mathrm{Al}$ oxide films. Therefore, it was apparent that the barrier type of $\mathrm{Al}$ oxide film was formed more quickly with ECAP than without in a neutral solution. These results fully correspond to the time-dependence of the corrosion potentials in $\mathrm{Na}_{2} \mathrm{SO}_{4}$ solution containing $\mathrm{Cl}^{-}$ shown in Fig. 9. As discussed above, it can be assumed that the increment in rate of formation of $\mathrm{Al}$ oxide films, and therefore the thickness of the $\mathrm{Al}$ oxide film, also contributes to the improvement of pitting corrosion resistance of $\mathrm{Al}$ and Al-Mg alloy with ECAP.

To evaluate the polarization resistance for the corrosion reaction of $\mathrm{Al}$ and $\mathrm{Al}-\mathrm{Mg}$ alloy, the $\mathrm{AC}$ impedance was measured at the corrosion potential in a solution containing $0.1 \mathrm{~mol} / \mathrm{L}$ of $\mathrm{Na}_{2} \mathrm{SO}_{4}$ and $300 \mathrm{ppm}$ of $\mathrm{Cl}^{-}$. Figure 11 shows Cole-Cole plots for $\mathrm{Al}$ and $\mathrm{Al}-\mathrm{Mg}$ alloy measured after immersion in the solution for an hour. The diameters of the Cole-Cole plots of $\mathrm{Al}$ and $\mathrm{Al}-\mathrm{Mg}$ alloy increased with ECAP, indicating that polarization resistance to the corrosion reaction increased with ECAP. The increase in polarization resistance with ECAP can be ascribed to the increase in oxidation rate of $\mathrm{Al}$. 

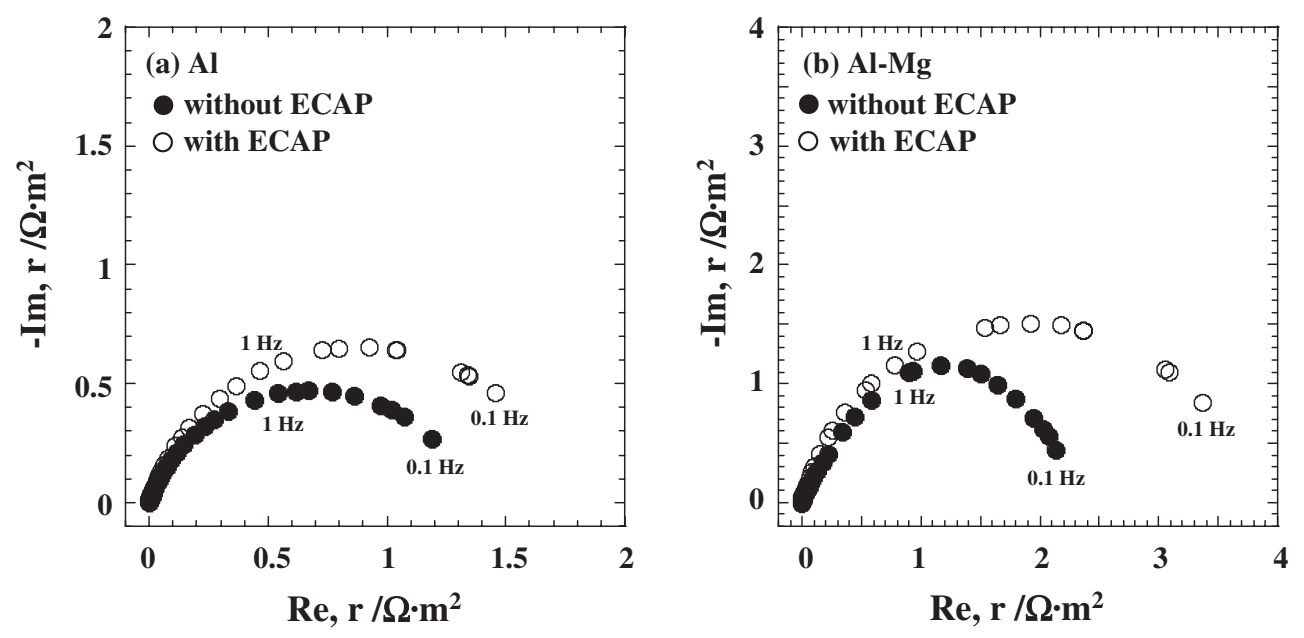

Fig. 11 Effect of ECAP on the Cole-Cole plots of Al (a) and Al-Mg alloy (b).

\section{Conclusion}

The effect of reducing the grain size by ECAP on the pitting corrosion resistance of $\mathrm{Al}$ and $\mathrm{Al}-\mathrm{Mg}$ alloy was investigated using electrochemical techniques. The potentials for pitting corrosion of $\mathrm{Al}$ and $\mathrm{Al}-\mathrm{Mg}$ alloy were clearly shifted to the noble direction by ECAP, leading to improvement in pitting corrosion resistance. $\mathrm{Al}$ and $\mathrm{Al}-\mathrm{Mg}$ alloy contained such precipitates as Al-Fe intermetallic compounds and trace quantities of $\mathrm{Si}$, around which pitting corrosion occurred. ECAP pulverized these precipitates. It is evident from the time-dependence of corrosion potential and the polarization resistance for corrosion reaction that the rate of formation of $\mathrm{Al}$ oxide films increased as a result of the ECAP process. Therefore, it was concluded that the improvement of pitting corrosion resistance of $\mathrm{Al}$ and $\mathrm{Al}-\mathrm{Mg}$ alloy with ECAP was caused by both decreasing the size of precipitates which acted as cathodes during corrosion and increasing the oxidation rate of $\mathrm{Al}$.

\section{REFERENCES}

1) H. H. Uhlig: Corrosion and Corrosion Control (in Japanese, Sangyo
Tosho, Tokyo, 1968) pp. 320-332.

2) G. Ito: Corrosion Science and Engineering (in Japanese, Corona Publishing Co., Tokyo, 1973) pp. 306-315.

3) R. Z. Valiev, N. A. Krasilnikov and N. K. Tsenev: Mater. Sci. Eng. A137 (1991) 35-41.

4) R. Z. Valiev, R. K. Islamgaliev and I. V. Alexandrov: Prog. Mater. Sci. 45 (2000) 103-109.

5) Y. T. Zhu, T. G. Langdon, R. S. Mishra, S. L. Semiatin, M. J. Saran and T. C. Lowe: Ultrafine Grained Materials II, The Minerals, (Metals \& Materials Society, Warrendale, PA, 2002).

6) Z. Horita, M. Furukawa, M. Nemoto and T. G. Langdon: Mater. Sci. Tach. 16 (2000) 1239-1245.

7) Z. Horita: J. Jpn. Weld. Soc. 74 (2005) 88-91.

8) Z. Horita: Materia Japan 41 (2002) 422-426.

9) M. K. Chung, Y. S. Choi, J. G. Kim, Y. M. Kim and J. C. Lee: Mater. Sci. Eng. A366 (2004) 282-291.

10) A. Balyanov, J. Kutnyakova, N. A. Amirkhanova, V. V. Stolyarov, R. Z. Valiev, X. Z. Liano, Y. H. Zhao, Y. B. Jiang, H. F. Xu, T. C. Lowe and Y. T. Zhu: Scripta Materialia 51 (2004) 225-229.

11) Z. Horita, T. Fujinami, M. Nemoto and T. G. Langdon: Metallurgical and Mater. Trans. A 31A (2000) 691-701.

12) Saisin Hyomen Syori Gijyutsu Soran (in Japanese, Sangyo Gijyutsu Service Center, Tokyo, 1987) pp. 524-528.

13) J. R. Davis: Corrosion of Aluminum and Aluminum Alloys (ASM International, UAS, 1999) pp. 29. 